\title{
From Ethnocentrism to Transculturalism A Film Studies Pedagogical Journey
}

\author{
Helen Yeates, MARgaret \\ McVeIgh AND TESS VAN HEMERT \\ QUEENSLAND UNIVERSITY OF TECHNOLOGY
}

The teaching of transnational film studies has the potential to provide for tertiary students an extraordinarily rich range of differing, sometimes conflicting, but always engaging transcultural insights and understandings. This article will chart a particular cultural studies case study involving the delivery, both in the past and looking towards the future, of certain pedagogical practices in relation to an undergraduate film studies unit. ${ }^{1}$ In late 2009, as part of a Queensland University of Technology Learning and Teaching research initiative titled Internationalising the Curriculum, the authors were funded by the Creative Industries Faculty to undertake a review of an advanced film studies unit, International Cinema, in order to assess the ongoing effectiveness of the particular unit, as well as to map the ways in which International Cinema may be renamed and reframed as an innovative pedagogical model for 'internationalising the curriculum'.

As part of a Bachelor of Fine Arts (Film and TV Production) course, International Cinema was designed and approved in 2001, the year the Creative Industries Faculty was formed. ${ }^{2}$ From its inception, International Cinema 
incorporated an emphasis on how possible links could be made between critical theory and creative practice, between cultural studies and film production, through engaging with relevant community cultural industries and through an understanding of relevant creative industries throughout the world. Over a thirteenweek semester, students are encouraged to examine critically such national or transnational cinema cultures as French, Spanish, pan-European, Japanese, Mainland Chinese, Hong Kong, Iranian, Mexican and Indian. At various times, Cuban and South African cinema have also been studied, and South Korean cinema is being considered for a possible future inclusion. ${ }^{3}$ It could be argued that the various iterations of this unit over the past nine years have already demonstrated aspects of an evolving pedagogical 'innovation' on several fronts. Instances include the careful choice of films screened for in-depth study, such as Amores Perros, La Haine and The Circle; 4 the application of a philosophy involving transnational film theory, combined with an emphasis on social justice issues to stimulate transcultural debate and help bring about changes in attitudes and values; the industry and community immersion pathway aspect of one very popular assessment item involving participation in an international film festival; and the creative industries context in which the unit is conducted, with the emphasis on developing a synchronicity between cultural studies theory and creative practice. Along with refining further the social justice component, we have been interrogating film studies theory as well as pedagogical advances in the field, in order to build a timely, more robust 'internationalised curriculum'.

In 2009, we attempted to devise an appropriate methodology for researching the further 'internationalising' of International Cinema. Ultimately, we chose Robert Stake's 'intrinsic' case study approach, when the case itself is of interest and the findings can be seen to add up to a 'valued particular', providing insights with multiple perspectives that tolerate ambiguity and complexity. ${ }^{5}$ In addition, our work follows that of Darla K. Deardoff who argues that, even though researching this particular educational field is quite difficult and underdeveloped at this stage, the most effective means of investigating significant shifts in intercultural competence include those that are both qualitative and quantitative in nature. Examples include evaluations, interviews, observations, case studies, analysis of narrative diaries, focus groups, dialogues, workshops, and student papers and presentations. ${ }^{6}$ Within 
the 'intrinsic' case study approach, we employed several qualitative research strategies such as conducting focus groups and a close analysis of student narrative diaries and online evaluations, as well as a study of comparable film units worldwide. ${ }^{7}$

As we found quite early in the research, enacting a viable 'internationalised curriculum' involves an interrogation of such terms as 'international', 'multicultural', 'intercultural' and 'crosscultural', all of which, as Astrid Gesche and Paul Makeham note, tend to assume that one's own cultural orientations remain unchanged. To extend and refine the internationalising paradigm, they posit the preferred term 'transcultural' as a desired competency in the education and development of students' cognitive processes, in an era of rapid change and connectedness: 'Transcultural competencies are recursive, dynamic, fluid and evolutionary, and characterized by constant renewal and adaptability to change'.8 Furthermore, these authors illuminate the difference between 'intercultural' and 'transcultural'. For them, the focus of the former is on aspects of difference and seeks to 'understand, respect and accept the "other"', while transculturality relates to 'commonalities and connections, without intending to homogenise cultures or establish monocultures'. However, they note that even though transculturalism is a lifelong journey, unlikely to be achieved in the limited duration of a formal education, the same enlightened pedagogies for change can assist students for the future by 'providing requisite skills and attitudes, and fostering dispositions which will assist their journeys according to their life circumstances'. They conclude that what 'ought to be achievable through formal studies is a critical examination of the centrality of culture in shaping and influencing a person's worldview'. Hence, a socially just outcome as a result of this educational process is the ultimate goal. ${ }^{9}$

Ideally, the significant outcomes of any pedagogical strategy framed within an 'internationalised curriculum' (limited though the term may be) would be the development and refinement of 'transcultural' skills and competencies, which all students will take with them beyond the academy. Such a critical form of transculturality therefore informs this case study of the International Cinema unit, as part of the university's wider philosophical and pedagogical project of 'internationalising the curriculum'. Furthermore, regarding the cultural studies context of this project, Daya Kishan Thussu's work is useful and illuminating. He 
argues that there have been three 'interventions' in the development of 'media studies' as a broad arena of study within cultural studies: feminism ('first intervention'), race and ethnicity ('second intervention'), with internationalisation being the 'third invention', as a form of 'de-Westernization'. While it is arguable that this tripartite, interventionist model does apply directly and comprehensively to the field of tertiary film studies as well, one of our guiding contentions links closely with his persuasive idea that 'the globalization of media together with the globalization of higher education' should challenge us to 'invest in new research angles, approaches and methodologies', along with more innovative pedagogies. ${ }^{10}$

Thus, through this current investigation we have explored the possibilities of encouraging a process of transculturalism, or a form of 'de-Westernization', in an Australian tertiary institution through the study of transnational cinema. Thusso's dual pressure points-the emergent globalised infrastructures of both the media (including film) and higher education-provide a promising dialogical lens through which to gather and view our research data. From this viewpoint, we have been searching for the ways in which studying such a cultural studies unit in higher education may bring about a special kind of transcultural change in attitude, particularly among largely ethnocentric Australian students who have grown up under the right wing, conservative government headed by John Howard, prime minister from 1996 to $2007 .{ }^{11}$

\section{—Why INTERNATIONALISE? A CHALLENGE TO TERTIARY EDUCATION}

This article will explore the three main areas that have emerged from our research thus far. It will first look at the debates circling the notion of 'internationalising' the curriculum and related critical pedagogies in tertiary education, beyond the hollow rhetoric around simply attracting more international students; second, analyse the 'intrinsic' case study data gathered, both recently and in the past, on the film studies unit under investigation; and third, connect the findings of this data analysis with current thinking in the field about the kinds of pedagogical paradigm shifts needed to deliver a genuine 'internationalised' film studies unit in the future. Given our acknowledgment of the significance of the 'transculturalising' process, we argue that one catalyst for changing students' attitudes involves a further embedding of social justice issues within the film curriculum. Based on our observation and experience 
in teaching the unit already, we consider that this would help facilitate the desired changes in largely ethnocentric students' attitudes and values relating to transcultural awareness, while at the same time foster a broader academic discourse, 'socially committed, and humanist in outlook'. ${ }^{12}$ As films may be seen as potent representational 'sites of discursive contestation' and discovery, 13 film students themselves may learn 'intercultural competence', ${ }^{14}$ and be inspired to be agents of transcultural change.

We are exploring, therefore, the possibilities of developing certain creative pedagogical strategies within a semester-long study of diverse national/transnational cinemas, and whether such strategies might become significant critical facilitators for attitudinal transformation, which would seem to be at the core of an authentic 'transculturalising' shift. Current research in the field indicates that one of the most significant factors affecting the internationalised pedagogical journey of any student is the specific and strong statement in 'graduate outcomes' regarding the development of intercultural understandings, along with the subsequent curriculum embedding of two related key areas of internationalisation-'globalisation' and intercultural competence. 15

Queensland University of Technology aims to graduate students who exhibit both professional and intellectual 'knowledge and skills pertinent to a particular discipline or professional area', as well as the 'intellectual and personal skills of critical, creative and analytical thinking, effective problem-solving and communication skills, the ability to work independently and collaboratively, self reliance and leadership, and the capacity for life-long learning'. Most importantly in terms of internationalising the curriculum, the driver for this study, QUT aims to graduate students who are able to demonstrate 'social and ethical responsibility and an understanding of Indigenous and international perspectives'. This key 'graduate capability' encompasses, among other relevant professional, intellectual, social and cultural attributes, a 'recognition and appreciation of gender, culture and customs in personal and community relations' within these crucial perspectives. ${ }^{16}$ In addition, this university specifically addresses the imperative of internationalising the curriculum in its current Learning and Teaching Plan. This plan includes the policy to 'integrate cross-cultural and international dimensions into curriculum design and learning environments' by way of encouraging 'an inclusive, dialogic teaching and 
learning environment for the development of students' understanding of the cultural, Indigenous, and international contexts' and incorporating 'specific reference to contemporary international and local content and context'.17

In the subject under scrutiny, International Cinema, with its stated aim of providing students with the opportunity 'to explore different cultural and political issues through film, one of the most significant popular cultural products throughout the world', we have specifically embedded QUT's desired graduate capabilities within our statement of graduate outcomes. The graduate of International Cinema is one who will demonstrate a "knowledge and understanding of a range of non-Hollywood national cinemas from various countries throughout the globe; and comprehend the social, political and historical contexts of these cinemas'.18 In short, our aim has been that the graduate of International Cinema would demonstrate the key outcome of being 'internationalised', which is a core intercultural competence. The unit's objectives, however, clearly need to be updated and refined in the light of new research in the field of internationalising higher education, and also in relation to our own findings as to whether the reality has measured up to the policy rhetoric.

Deardoff has noted the lack of specific indicators or measurement of the characteristics of the 'internationalised' or the 'interculturally competent' student.19 Thus, while there has been some debate on what constitutes 'internationalisation', little specific notation of what it means 'to be internationalised' figures in the literature. Intercultural engagement is at the heart of what could be termed intercultural education, which 'strives to develop critical engagement, self reflection and sensitivity towards any aspect of interaction and communication between "self" and "others"'.20 For Betty Leask, such engagement requires:

an understanding of how the languages and cultures of others influence their thoughts, values, actions and feelings, and it is frequently argued that this understanding of others must be predicated by an appreciation of the ways in which our own language and culture influence our actions, reactions, values and beliefs. ${ }^{21}$

The crucial issue therefore centres on attitude, which would seem to be the enabling factor of a multilayered, intercultural engagement. In any internationalising 
pedagogical process, one significant outcome is the gradual gaining of a new form of tolerant, transnational citizenship. ${ }^{22}$

In order to embed internationalised qualities in curricula, Leask has developed graduate generic indicators for use in program planning across the University of South Australia campus. She elaborates, in some detail, on the attributes of 'internationalised' students. According to her research, such students would demonstrate a number of attributes, including thinking interculturally from a 'variety of perspectives', having an awareness of the perspectives of their own culture and other cultures, and valuing diverse languages and cultures. 'Internationalised' students would also understand the subtle 'relation between their field of study locally and professional traditions elsewhere', at the same time linking 'multicultural diversity to professional practice and citizenship'. ${ }^{23}$ Leask's study provides useful data to inform our future planning, in that she addresses specifically the affective components of being 'internationalised'. Thus, the process of creating material conditions for the successful 'internationalising' of our film studies curriculum would appear to involve the ongoing challenge of integrating particular cognitive, affective and operational categories of teaching and learning, with the aim of initiating more heightened transcultural learning within a pluralised sphere of cultural studies endeavour. ${ }^{24}$ Such internationalised learning may then sustain and inspire students as they proceed into postgraduate courses, as well as beyond the academy into employment in various creative industries.

In this context, it is important to consider more fully the pedagogical dimensions of 'internationalising the curriculum' emerging out of the different, but inextricably linked, problematic processes of economic 'globalisation' and cultural internationalisation. As Richard Edwards and Robin Usher argue, little attention had been paid to 'questions of pedagogy in relation to globalisation' prior to 2000. In the new millennium, they claim, academics have developed a more effective focus on the 'economic, political and cultural significance of globalisation'. ${ }^{25}$ However, along with the imperialist, homogenising overtones of 'globalisation', the notion of 'internationalisation' itself is not without contention. Treatises regarding internationalisation and globalisation in higher education have largely dealt with the institutional, economic and pedagogical dimensions of hosting the 'international' student. ${ }^{26}$ As noted before, this current case study is not considering the 
'internationalisation' of the academy from that narrow, contentious perspective. Moreover, Jane Knight posits that the term 'internationalisation' is a shifting one, differing according to who the key stakeholders are. She argues that the term may have different meanings in the related yet competing fields of curriculum and technological delivery, research partnerships, the profile of the student cohort, or even the commodification of education as a global export commodity. ${ }^{27}$ Given the relatively scant material available on effective pedagogical strategies for internationalising the curriculum, this current case study, though modest in scope, aims to be a fresh, more grounded contribution to the field.

—CRITICAL TRANSNATIONALITY AND TRANSCULTURAL ALTERITY: NEW DIRECTIONS IN PEDAGOGICAL PRACTICE IN FILM STUDIES

It would seem that tertiary students of 2011 can look forward to the life of the transnational citizen where they telecommute and communicate beyond geographical or chronological 'borders'. From an Australian postcolonial perspective, Ien Ang and Jon Stratton urge cultural studies academics to think beyond historically inherited ethnocentric borders and carve out a practice and 'a terrain for a critical transnationalist perspective in cultural studies'. ${ }^{28}$ In relation to creating more specific, innovative pedagogical practices and a 'critical transnationalist' 'terrain' for this case study, authors including Sanjay Sharma, Meaghan Morris, Konrad Ng and Yingjin Zhang have also inspired and informed our journey towards developing such a perspective within transnational film studies itself. ${ }^{29}$ These authors all question Eurocentric ways of knowing and learning, and promote various forms of critical transcultural learning through film studies. For instance, Morris presents the need for 'imagining film studies transnationally', raising issues around non-national models of analysis. ${ }^{30}$ Arguing further against 'a strict national cinemas approach' in relation to teaching Asian cinema, Ng challenges ethnocentrism in order to gain a form of transculturalism through film studies, posing the question 'How can one use Asian cinema to help develop Asian studies teaching and learning at American institutions of higher education?' Seeing advantages in the 'process of using film to incubate associations between concepts and experience in ways that extend beyond national contexts', he finds, in particular, the 'work of the alternative film culture of China's so-called 6th Generation 
filmmakers useful in articulating this pedagogical stance'. For Ng, Jia Zhangke's The World highlights 'the impoverished lives behind the spectacle of globalization', and he points to Zhangke's use of 'the cinematic medium to ask viewers to consider the notion that dislocation is taking place between an increasingly global world and its myriad representations' ${ }^{31}$

Calling for a similar investigation into modes of inclusion of cultural diversity and 'cultural hybridity' into the film studies curriculum, Sharma asks, 'what kinds of encounters with "otherness" do radical multicultural pedagogies engender?' He explores the creative yet challenging 'im/possibilities' of an 'alterity pedagogy' through a case study of teaching the British South Asian film Bend It Like Beckham. ${ }^{32}$ Seeking to move 'beyond (though not abandoning) representational teaching strategies', he calls for an ethical activation of 'the affective investments of students by making connections that offer the potential of other ways of living with difference'. ${ }^{33}$ His work with its strong promotion of the affective domain shines a useful light on the similar issues we are pursuing in our case study.

Dealing more specifically with defining and theorising the field of international/transnational film studies itself, rather than taking a particular 'case study' approach, Yingjin Zhang puts forward the notion of 'comparative film studies being a subfield larger than transnational film studies', arguing that film scholars should move beyond the 'unsettled' term 'transnationalism' (largely because of 'the multiple interpretations of the national' within the meaning), to what he calls 'transcultural visuality', linked with David Bordwell's work on the poetics of 'transcultural spaces' in Chinese film. For Zhang, 'comparative film studies ... must broaden its vision to include relevant aesthetic, cultural, economic, socio-political and technological aspects of international cinema'. ${ }^{34}$ Again, this is an illuminating viewpoint, giving an emergent comparative film studies edge to the creation of a transcultural 'space' for film studies, beyond the constraints of the 'national'. It has become abundantly clear that, as part of the process, we need to change the dated title 'international cinema' and re-examine the content of our film studies unit, in consideration of these persuasive critical arguments within the field. 
-TRANSNATIONAL CINEMA: TOWARDS A POST-THIRD-WORLDIST PEDAGOGICAL SPECTACLE

In recent times, transcultural film theorists have tended to focus on both the 'micro' and 'macro' dimensions of the field, investigating the forces that link films, filmmakers, audiences and film industries across nations and borders. In contrast to Zhang and Morris, for instance, Elizabeth Ezra and Terry Rowden are not so concerned about the confining 'national' lurking within the term 'transnational', defining transnational cinema as that which 'transcends the national as autonomous cultural particularity while respecting it as a powerful symbolic force'. 35 It is noteworthy here that transnational cinema theory itself goes beyond earlier Third Cinema theory. The latter arose in the 1960s in response to worldwide liberation struggles and decolonisation movements, and was essentially a 'call-to-arms' against social injustice and post-imperial exploitation. ${ }^{36}$ In distinguishing itself politically and aesthetically from Hollywood and European 'autuerist' cinemas, Third Cinema was often categorised for its contentious political and social commentary, establishing it as a 'cinema of opposition'. ${ }^{37}$ This 'three cinemas' theory placed Third Cinema in juxtaposition with First and Second Cinemas. Essentially, this was commonly interpreted as positioning 'First Cinema ... [as] a cinema of entertainment, Second [as] one of intellect and interiority and the Third [as] one of political radicalism'.38 While over simplified, the edgy political lens often synonymous with Third Cinema positioned the medium as a potentially powerful tool for triggering social awareness and change.

However, even from its conception the notion of Third Cinema has been problematised by many film theorists as limited in its failure to account for the significant and complex differences across so-called 'Third World'/developing world peoples and their cinemas. ${ }^{39}$ The disregard for local specificity, particularly in the theorising by First Cinema film critics, led not only to a homogenisation of Third Cinema as a whole, but also to preconceived ideas about the expected content of such films. Recognition of a need for a fluid definition of Third Cinema theory feeds into more contemporary debates that argue for a shift toward a more heterogeneous identification of individual filmmakers, under the rubric of transnational cinema. Thus, transnational cinema theory directs the focus away from clearly delineated national cinemas toward a more expansive system of cinema, in which locally specific stories can cross national borders, and distinct national cinemas become 
increasingly hard to grasp and define. Third Cinema theory has also failed to take into account challenging multiplicities within the north/south divide, in relation to developing world cinemas and minority cinemas in developed nations.

More recently, Post-Third-Worldist debates have emerged from the work of theorists such as Ella Shohat, who argues for highlighting a hither-to neglected, feminist approach to 'Third Cinema' films. Shohat establishes the thought-provoking viewpoint that:

[in] the face of Eurocentric historicizing, the Third World and its diasporas in the First World have rewritten their own histories, taken control over their own images, spoken in their own voices, reclaiming and reaccentuating colonialism and its ramifications in the present in a vast project of remapping and renaming. 40

Furthermore, Shohat's post-Third-Worldist approach argues for a feminist 'remapping' articulation of a 'contextualized history for women in specific geographies of identity'.41 This fascinating rewriting of specific identities and histories for women has moved some way toward correcting what was a significant silencing of women's voices within Third Cinema theory and practice. Shohat's definition of 'post-Third-Worldist' does not deny the validity of some aspects of the Third-Worldist approach within cinema studies, but rather she simultaneously identifies and questions its contradictions.

In particular relation to these debates, we embrace the way that post-ThirdWorldist, transnational cinema theory emphatically moves away from Third Cinema's patriarchal ideas of a closed national cinema. For instance, Andrew Higson argues that neither cultural diversity nor cultural specificity in film culture can be confined within the realms of 'national' cinema, simply because the communities imagined in cinema are much more likely to be either locally specific or transnational. ${ }^{42}$ The limiting nature of national cinema is not entirely dismissed by critics; rather, it has been reworked to accommodate a more fluid definition of the 'national', which includes not only feminist, but also queer, diasporic and transnational identities. ${ }^{43}$ Shohat concurs, stating that the 'diasporic and Post-ThirdWorldist films ... do not so much reject the "nation" as interrogate its repressions and limits, passing nationalist discourse through the grids of class, gender, sexuality and diasporic identities'. ${ }^{4}$ 
Thus, transnational cinema is characterised most significantly for its examination of the relationship between the local and the 'global'. This emerging conceptualisation of transnational cinema is useful to this research, as it 'enables us to better understand the changing ways in which the contemporary world is being imagined by an increasing number of filmmakers'. ${ }^{45}$ Although transnational cinema as a theory is still criticised for its propensity to homogenise cultures, there is a general consensus among critics that this theory provides a more complex lens through which to view contemporary cinema in all its manifestations. Jigna Desai contributes further to transnational and diasporic film theory debates, stating that:

South Asian Diasporic cultural production is ideally poised to engage strategically and intellectually the macrological (i.e., capitalism and imperialism) and the micrological (i.e., discourses of everyday life) to enact analyses that examine the mutual constitution of the global and the local. 46

Such an engagement between local stories and global reception, as well as the global impact on local filmmaking, highlights an emergent, vibrant transnational cinema. This therefore poses a significant challenge for us to incorporate a broader transcultural vision in the development of a cutting-edge pedagogy for film studies.

-INTERNATIONALISING INTERNATIONAL CINEMA: THE CASE STUDY-IN-ACTION

Pepi Leistyna laments the 'disconnection of theory from practice' within cultural studies; his particular aim is to remove the discipline of cultural studies from being an 'abstract discipline' to being 'grounded in tangible life experiences and struggles for social justice around the globe'. 47 A similar social justice advocacy has been considered as integral to our unit International Cinema from its inception. Linked with this current 'Internationalising the Curriculum' Creative Industries Faculty initiative, another particular aim of this research is to ground more tangibly this unit's agenda regarding social justice advocacy in the future. In part, this work will entail reaching out across uncertain pedagogical borders for new ways to find a 'disruptive force and performative affect' in the study of transnational cinema. ${ }^{48}$ This venture has come to involve interrogating notions of transcultural pedagogical practice, and investigating how these can be usefully forged with emergent critical theories about post-Third-Worldist transnational cinema itself. 
The work of comparative educational theorist, Anne Hickling-Hudson, also from Queensland University of Technology, promotes and demonstrates the practice of 'inclusive' education for concrete social justice outcomes.49 She poses the following question to all teachers and researchers in higher education: 'How do we develop culturally relevant pedagogy ... in the interests of equity and social justice?' Embracing her argument that an 'ethnocentric Western curriculum is standard fare' in Australia, we aim to engage in more transdisciplinary, transcultural work with colleagues such as Hickling-Hudson, in order to bring about more 'culturally relevant' pedagogical processes. Over many years through her studies in comparative education, she has striven to contest deeply embedded ethnocentrism through her own pedagogical practices, working towards a form of transculturalism, which she terms 'critical interculturalism'.50

With the specific aim of grounding such debates around local/global struggles for social justice into the film curriculum via more effective teaching and learning practices, we are inspired by our research to continue to be scrupulous in the choice of specific films to study. As mentioned before, several key films which have stimulated much debate regarding social justice issues are, for instance, Amores Perros (Love's a Bitch), La Haine (Hate) and The Circle. Others also in this category are Caché (Hidden), Raise the Red Lantern, Water and even Le fabuleux destin d'Amélie Poulain, with the latter film's disturbingly monocultural, exclusionary aesthetic.51 Moreover, these films have been complemented by the students' engagement in an immersive assessment exercise with the Brisbane International Film Festival (BIFF) each year. ${ }^{52}$ Through the key positioning of such intercultural elements, we would argue that the students have been developing for several years a form of 'global cine-literacy'53 as well as grounded insights into transcultural issues, raised both within the teaching and learning activities on campus, and within the film culture context beyond the academy; for instance, by engaging with transcultural filmmakers in post-screening question and answer (Q\&A) sessions and seminars run by the BIFF organisers. On this point, one Australian interdisciplinary studies female student from 2009 wrote the following in her autobiographical journal about her participation in the festival, relating her thoughts on a seminar titled Colourise BIFF: Screen Globally, Shoot Locally: 
What interested me most both about this seminar and the films I saw by key Indigenous filmmakers from across the world was the way they presented the medium of film as a powerful device for instigating change. I discovered such elements of change might include the abolishment of cultural boundaries and formation of new connections between communities; strengthening and preserving cultures through film documentation; breaking of cultural stereotypes; and engagement with the idea of 'place' in order to better understand the world in which we live. The speakers had been asked: How do we place ourselves locally and globally?

In the dynamic film festival environment, it would appear from our research that such students gradually become aware that a study of transnational cinema directs the focus away from national cinemas, in the interests of social justice and transcultural tolerance. For instance, after seeing the New Zealand film The Strength of Water within the Colourise BIFF strand, the same student commented enthusiastically that this was her 'favourite film at the festival'. To her, the film was 'successful in bringing values and perspectives of Indigenous peoples to the world'. In such a context, therefore, it could be argued that transnational cinema has been experienced directly by this student as a medium not only for raising her awareness on local/global social justice issues, but also for her experiencing an affective shift in transcultural understanding.

In relation to such a 'shift', through his examination of the cultural politics of the 'international' film festival scene, Julian Stringer discusses the flows of transcultural film exhibition, with a specific focus on the temporal and spatial characteristics of the film festival in any city. He suggests that film festivals function as places for the 'establishment and maintenance of cross-cultural looking relations', as a 'parliament of national cinemas'.54 While it is difficult in the university environment to replicate the scale of an international film festival's 'cross-cultural looking relations' function, we note that our students' festival reports document what could be termed a distinct pedagogical innovation in relation to communitybased learning. Since 2001, we have been reaching out from the so-called 'ivory tower', across the 'borders' into the city's film cultural community, integrating, as feasibly as possible, the festival itself, cultural workers, international filmmakers 
and other relevant film cultural events and participants into the International Cinema unit.

—STUDENT JOURNALS: CHARTING THE SHIFTS IN TRANSCULTURAL SENSIBILITIES

Henry Giroux has argued that 'viable critical pedagogy needs to [analyse] how ideologies are actually taken up in the voices and lived experiences of students as they give meaning to dreams, desires and subject positions they inhabit'. Through the students' personal journeys in studying this film unit, we have attempted an enlightened pedagogical process by setting for assessment a critically reflective journaling of the festival experience (as illustrated above). We have been using this form of self-reflexive autobiographical assessment over the past eight years, attempting to document the 'voices and lived experiences of students' as they articulate their experiences when engaging with transnational films at the Brisbane International Film Festival. To illustrate further, one Australian performance studies student from 2004 has summed up her festival experience, giving her own special inflection to her 'dreams, desires and subject positions'. ${ }^{55}$ Her response involves affective elements of joy, mixed with a more enlightened humanitarianism, and an urge to travel the world:

I have thoroughly enjoyed this [film festival] assignment ... I've laughed, cried, yelped, gasped. I feel invigorated but now I have itchy feet to do some more travelling. One of the most amazing feelings though is the sense that humanity will prevail. Through education of the masses (using mediums such as film) we can gain a better understanding and appreciation of the many diverse cultures and societies, and hopefully ease the suffering of those less fortunate.

Another female Australian film production student from the same year reflected her own distinctive kind of excitement and inspiration, straightforwardly recording her thoughts and feelings at the very start of her festival encounter:

Although I enjoy Hollywood and at times its predictability, international cinema's a nice change from the studio system's factory style of the same story in a different wrapping. Hmmm this looks like it's gonna be a costly venture. Tickets (so far) $\$ 100$, expected coffees who knows? Meeting Jafar Panahi, priceless. ${ }^{56}$ 
An Australian male creative writing student commented further in his 2004 festival journal on Panahi's film Crimson Gold:

This was the first Iranian film I had ever seen. It was not only a wonderful example of great cinematic talent but a delightful and insightful director passionate about his work and open to the ideals of freedom, liberty and equality.

In the light of Panahi's recent very disturbing persecution and incarceration in Iran, it is especially poignant now to read the comments of another Australian female film production student from the 2004 cohort, after attending his film screening and the talk that followed:

I was incredibly impressed by Panahi's intelligence and dedication to leaving conclusions about his films to viewers and his refusal to explain his own ... He assumes intelligence in the viewers ... allowing for many interpretations. This view made me want to clap and cheer as it is a sentiment I share and one seemingly so rare in our analytical age. Also I was impressed by the incredible moral standing of Panahi. The refusal to be fingerprinted and his subsequent cuffing for 16 hours at JFK airport in transit would have required a huge amount of stoicism and endurance.

Experiencing firsthand the films and views of an Iranian filmmaker of Panahi's stature was a significant element that affected many students that year, giving them fresh insights into the politics of transnational cinema and related issues of social justice, directly from the filmmaker's perspective.

In future, we aim to expand on this learning/assessment process, by adapting further Hickling-Hudson's suggestion of a reflective 'cultural autobiography', threaded throughout the unit and dealing not only with ethnicity but also with 'how issues of social class and gender intersect with these experiences'. ${ }^{57}$ Other research affirms and recommends this pedagogical method. Hunter, White and Godbey, for instance, argue that in order to progress from ethnocentrism to transculturalism, a person should first 'attempt to understand his or her own cultural box before stepping into someone else's'. This, they say, 'can be accomplished by participating in a series of self-reflective activities that focus on one's cultural barriers and boundaries'.58 
From 2011 onwards, we want to expand this autobiographical exercise throughout the whole semester, and not solely in relation to the film festival assignment. Initially, this will involve a self-reflexive recording by students about how they have viewed, experienced and understood other cultures and issues of social justice prior to studying transnational cinema; secondly, an ongoing documentation of their experiences with the films screened, the lectures, the readings encountered and the tutorial discussion topics, as well as with a community-oriented, film festival/film culture assessment option; and finally, a critical reflection and evaluation report of their transcultural understandings and experiences, and how they may have been personally and culturally transformed by studying the unit.

—DELVING DEEPER, CLIMBING MOUNTAINS: LISTENING TO STUDENTS IN INTERNATIONAL CINEMA

In late 2009, as a result of gaining funds for this current project, we organised several focus groups with students to supplement the findings from journals as reported above. In the 2009 cohort's focus group, a particular transcultural perspective was frankly expressed by a Singaporean Chinese female student majoring in film studies and marketing. She was surprised by some of her fellow students' reactions to the intensity of the Brisbane International Film Festival experience, reflecting that 'for certain students who have never seen a nonHollywood film, they are taken aback and go "Whoa! This film is crazy"'. Initially, she wondered about such Australian students, asking them: 'What have you been doing?' Nevertheless, she finally realised that she 'couldn't really blame them', as, in her view, 'certain people just don't want to watch films with sub-titles ... I have been watching films with sub-titles my whole life'. She went on to explain that, with Hong Kong cinema, for instance: 'Although I'm from Singapore and speak Chinese, I have no idea how to speak Cantonese'. From her professed 'open-minded' perspective, she pointed out: 'You go there [to a film festival screening] thinking I don't really know what this is film is about ... but you come out and feel you have climbed a mountain'.

In evaluating the film studies unit, one female Australian creative writing student in the 2009 focus group said that International Cinema was 'one of the few subjects that opened you up to the world'. A male Australian film studies and 
interactive media student found the unit to be 'really cool', as he felt 'really smart' because 'I've learned so much about all of these other cultures'. Overall from the focus groups, we have found that most of the students expressed their appreciation in the form of some positive pedagogical outcomes; for example, learning 'about the sociological importance of world film ', and understanding 'the different political and social backgrounds that films emerged from'. One Australian female education studies student particularly liked the pedagogical strategies such as the tutorial presentation and discussion based on readings and viewings, which 'provoked students into making their own judgments'. An Australian male education student enthused further: 'I have developed a love for internationally produced films', and 'this unit has really expanded my world view'.

Regarding the cultural and industrial contexts of the films screened, an Australian female interdisciplinary studies student felt that she had gained a significant critical perspective, in the form of 'a deeper appreciation how difficult it is for filmmakers in other countries to actually make films'. She further reflected that she now sees more clearly 'the processes and hindrances faced by diverse people in other cultures' who, 'despite all odds such as censorship and so on', are 'obviously feeling passionate about wanting to tell their stories and get them out there. So I think, from a cultural perspective, that's had the biggest impact on me'. In a similar vein, an enthusiastic Australian female journalism student from the 2008 focus group claimed that 'The unit highlighted for me what a valuable medium film can be for people not from developed nations to express their views'.

While some students stressed the enlightening sociological dimensions of both the contexts and practices of films and filmmaking, others significantly linked their experiences with transnational films to their own emerging aesthetic in relation to their creative practice, articulating interesting examples of the meshing of theory and practice. For instance, a Malaysian female student (2008) expressed that, as she did not have ready access to such films from Europe and Iran in Malaysia, this unit had 'broadened' her view, and was 'really well balanced with Second and Third Cinema films'. Moreover, as an intending cinematographer, she felt able to develop her own practice in new ways. An Australian male film production student (2009) commented that, while he had come to the unit 'with a smattering of understandings of transnational film', he had had to re-examine his preconceived notions, as well as 
appreciate a 'new form of inspiration' for his own productions. For instance, he professed that he had assumed all Indian films were 'pure Bollywood', but now, after seeing the independent diasporic films such as Water and Monsoon Wedding, ${ }^{59}$ he realised that this is not the case. He considered that he is now more invigorated in regard to his own productions, as well as 'looking with fresh eyes' at Indian and other nations' films: 'It's been really good for me with cinemas I haven't seen a lot of ... The films have given me ideas for my own films.'

Similarly, a female Australian performance studies student from the 2008 class discussed how studying international films made her want to apply new ideas in different ways in order to reframe her own performance practice. A key inspiration in this respect was gained from 'Iranian cinema, seeing how they [the filmmakers] used metaphor and poetic images to say and hide controversial things'. Struck by the filmic conventions used, she wants now to 'translate those into performance-the use of motifs, the use of a kind of magic realism'.

Other forms of student feedback have been drawn upon as useful complementary data for this Internationalising the Curriculum case study. Touching on attitudinal change through gaining deeper insights into other cultures, one student wrote online in anonymous feedback mode at the end of 2009:

This unit is a wonderful way of exposing students to other cultures and providing them with an insight into the personal, political and social issues faced in some of those other cultures. As a student who has a real interest in social justice, this unit has reinforced my belief that the creative industries-including the film medium-can be an effective, powerful and accessible tool to raise awareness, promote humanity, and to inspire people to become not only more tolerant of other ways of life but more interested in issues of globalisation (and its effects), and to challenge stereotypes and embrace diversity.

This student's positive view represents a definite trend that can be traced through the evaluative feedback, as many express that they had become 'more informed' and 'more culturally aware' than they were before studying the International Cinema unit. Another student stated that the 'best aspect' was 'othering Hollywood cinema'. Over many years, the majority of students in their online feedback have reported that they had rarely engaged with international films prior to the unit, and 
predictably, sub-titles seem to have been an initial stumbling block. However, most claim they soon 'managed to deal with this' and 'enjoy the films', with one student going further, writing 'This subject is rad [sic]. Focusing on a number of different countries has opened my eyes to cultural differences and increased my cultural sensitivity.' A noteworthy variation was expressed by one Australian male film production student in the 2008 focus group: 'I'd already seen most of the international films screened before.' Despite this atypical, extensive pre-knowledge, he did concede that, each week, 'I gained a greater understanding of the culture portrayed in the films'; for example, 'it was only after hearing about the Spanish political climate prior to Almodóvar's emergence as a filmmaker that I fully understood the significance of his filmmaking and storytelling methods', and 'his [Almodóvar's] radicalism inspired my own filmmaking especially on gender and sexuality themes'. From this brief snapshot glimpsed through the students' eyes, the content and the pedagogical practices in the unit can be seen to be fostering certain critical and aesthetic strategies relating to a creative praxis for social justice transformation in a higher education context.

\section{-EXPLORING BORDERLANDS: TOWARDS A VIABLE CRITICAL PEDAGOGY}

Taking up Morris's challenge regarding the unresolved thorny issue of how to theorise 'the insistent flow of images about "global" forces rolling round "borderless" worlds',60 our research acknowledges the importance of revisiting Borderlands theory as a critical pedagogy which, to an extent, takes into account the transnational ebb and flow of difference and multiple subjectivities in the advancement of educational theory.

C. Alejandra Elenes claims that 'the Borderlands is the discourse of people who live between different worlds'.61 Further, she argues that debates regarding the Borderlands gained currency in the late twentieth century, because of Chicano scholars' critiques of existing Western cultural theory paradigms (for example, postcolonialism, feminism, neo-Marxism) and, in particular, the study of discourses theorising marginality and identity formation in the globalised economy. ${ }^{62}$ In the context of the new millennium, Elenes suggests that a renewed 'analysis of the Borderlands can offer a way to advance educational theory' and practice. For her, 'the understanding of culture as fluid is a necessary move, since much of the 
education scholarship under the guise of multicultural education continues to represent culture and identity as static'.63 In addition, Elenes notes that the radical 1990s work of such theorists as Giroux and Peter McLaren on 'border pedagogy' has contributed to a reconceptualisation of Borderlands philosophy as a means of respecting and reconstituting the notion of cultural 'difference'.64

We aim therefore to pursue Elenes' reclamation of border pedagogy, linking the emerging notions of 'critical transnationalism' within film and cultural studies, and 'critical interculturalism' within pedagogy. ${ }^{65}$ For instance, Elenes cites Giroux's ideas on 'border pedagogy', with students' cultural 'border crossing' as an essential element in understanding and rethinking the shifting cultural significance of the dominant powers, an important consideration in the context of transnational cinemas in relation to resisting the globalised and globalising milieu of conventional Hollywood cinema. Moreover, Elenes points out the significance of McLaren's elaboration of the 'border pedagogy' concept, focusing on 'border identities', grounded in a form of 'critical narratology', thereby validating a pedagogical approach concentrating on "the development of "postcolonial narratives" that unfix, unsettle, and subvert totalizing narratives'.66 We also aim to incorporate a similar social justice approach in subverting such 'totalizing narratives', in order 'to deconstruct the problematic of essentialist notions of identity, culture, and difference', through the selection of transnational narrative films that may take students out of their various monocultural 'comfort zones'. Following Elenes, a key tenet for carving out a pedagogical terrain for internationalising the curriculum through 'critical transnationalism' is a considered reappraisal of what cultural difference means today. This transformative pedagogical aim may then effect attitudinal change, bringing about a special form of 'affect' and caring, which Gesche and Makeham hold as imperatives in the educational process of internationalisation. ${ }^{67}$

—IMAGINING THE FUTURE: CREATING NEW TRANSCULTURAL NARRATIVES

As we contemplate the most appropriate pathway towards designing a new iteration of our International Cinema unit within a reconceptualised 'border' pedagogical paradigm, we have been challenged by student feedback as well as by ideas relating to a broader transcultural vision of alterity. When considering the related 
phenomena of internationalisation in education, transnational cinema theory, cultural production and creative practice, the opportunity lies now in searching for some answers regarding how best to educate students through creating imaginative transcultural 'narratives' to live by. As Gillian Bottomley cautions:

The omnibus term 'globalisation' tends to evacuate local specificities and the continuous articulation between internal and external factors. It also carries a sense of inevitability and relative powerlessness, despite the celebratory messages that often accompany the concept. Several forests have already been destroyed in discussion of the concept and consequences of globalisation...

It is relevant to resist, therefore, the more ominous overtones of the formation of a 'global citizen', and seek anti-imperialist discursive constructions of the interculturally sensitive citizen, with 'the possibilities for the development of social competence and, by association, social citizenship'.68

We acknowledge also that there are new semantic and conceptual shifts occurring in the fields of education and film theory, where 'international' and 'internationalising' are now rather dated terms, and transnational, intercultural and transcultural ideas are gaining significant traction. The subtle differentiations gleaned from the relevant transdisciplinary academic literature provide us with the opportunity of building upon and improving the social justice foundations of 'critical transnationalism', as a fruitful means for 'internationalising the curriculum' in the context of QUT's Learning and Teaching framework and five-year plan.

In light of this, McLaren argues that the privileging of a form of 'critical selfreflexivity' is imperative for critical transcultural citizenship, and it therefore remains to work out how best to develop a 'coherent philosophy of praxis' within creative industries, bringing together, through an embedded transculturalism, material creative practices and critical creative analysis. ${ }^{69}$ While some students surveyed in our case study claim that engaging with transnational films has lifted their own creative practices in more enlightened transcultural ways, it would seem that there is still quite a long way to go to achieve, through teaching transnational film studies, an inventive, fluid connection of theory and practice as an ongoing rule, rather than as an exception. 
—TRANSCULTURAL ACTIVISM AND EMOTION: MOBILISING STUDENTS THROUGH AN 'EVOCATION OF AFFECT’

Finally, it could be argued that the creation of a viable pedagogical terrain in film studies for transcultural social justice outcomes is very promising. In relation to Latin American film studies, Laura Podalsky writes about the Cuban film Madagascar and the Mexican film Amores Perros, which carry out 'emotional work as well as or as part of their political work'.70 She investigates further the 'interface between affect, politics and history', arguing that 'the evocation of affect in film ... can have a mobilizing effect'. Following Thomas Elsaessar, she claims that films may evoke 'the affect of concern', touching 'a point where the self ... can experience otherness'. From this perspective, the study of films from other cultures can be seen to have the power to bring about 'empathy and identification ... in an active, radical sense of being "stung into action"'.71

The affective, transformative power of transnational film studies needs to be developed further in the future. At the same time, promising signs of a social justice activist inflection have been discussed here in relation to our students' documented experiences, especially at the Brisbane International Film Festival, where we can claim to have achieved the beginnings of an innovative, 'border crossing' pedagogy for the development of transcultural competencies. From this perspective, a male Australian film studies student sums up one aspect of his moving festival experience, with a 'call to action':

The [BIFF] seminar entitled Can Film Change the World? was an exciting presentation. One of the main points was that there has been a distinctive change in certain ideals that drive film. The panel of filmmakers explained that film's previous job was to 'represent the world'. However, there is a now a genuine conviction that film cannot only 'represent' the world, but can influence 'change'. They made it clear that it's not film that changes the world-it's actually people and activism. Film influences the changing of the world when people are stimulated, exiting the cinema talking about the film and its politics. 
Helen Yeates teaches and researches in film and television as well as in research methodologies. She supervises honours and postgraduate students across a range of disciplines in the Creative Industries Faculty at Queensland University of Technology. Recently her research interests have focused on practice-led research methods and creative pedagogies, and she is now and Adjunct Professor.

Margaret McVeigh has taught in Screen Studies at Queensland University of Technology for many years. She also teaches film history and screenwriting at Griffith Film School. She recently completed her PhD in Film and New Media at the University of Southern Queensland and is in the process of publishing this research.

Tess Van Hemert is currently a doctoral candidate and scholarship holder in Creative Industries, Queensland University of Technology, examining the relationship between emerging, transnational women filmmakers and international film festivals.

\footnotetext{
-NOTES

1 'Film studies' is seen here as being 'part of the wider field of disciplines and approaches' that has evolved into being called cultural studies. See Graeme Turner, Film as Social Practice IV, fouth edition, Routledge, Abingdon, Oxon, 2006, p. 59.

2 John Hartley and Brad Haseman have claimed 'The Creative Industries are those enterprises that are geared up to supply creative content to the information technologies (be they cultural forms, media, or new interactive or interoperative delivery systems), that have been or are being developed for business, retail, consumer or public applications in the context of the new economy, the information revolution, and the "network" society'. John Hartley and Brad Haseman (eds), Creative Industries: A Reader, Queensland University of Technology, Brisbane, 2000, p. 2.

3 The pan-European section, for instance, entails detailed work on the films of Krzysztof Kieślowski and Michael Haneke.

${ }^{4}$ Amores Perros (Love's a Bitch), directed by Alejandro González Iñárritu, 2000; La Haine (Hate), directed by Mathieu Kassovitz, 1995; The Circle, directed by Jafar Panahi, 2000.

5 Robert Stake, 'Case Studies' in Norman Denzin and Yvonne S. Lincoln (eds), Strategies of Qualitative Inquiry, Sage Publications, London, Thousand Oaks, New Delhi, 2003, pp. 134-64.

6 Darla K. Deardoff, 'Identification and Assessment of Intercultural Competence as a Student Outcome of Internationalization', Journal of Studies in International Education, vol. 10, 2006, pp. 248-50.
} 
${ }^{7} \mathrm{~A}$ brief online survey was carried out with the aim of gaining some insights into a global context for this study. Such documented information will also assist our decision in considering the best way forward for the unit currently entitled International Cinema. We sampled sixty-two Australian universities and twenty international universities that ostensibly offered comparable film courses. Twenty-eight of those surveyed appeared to have neither any relevant 'transnational cinema' units, nor any readily accessible information on the university website, while fifty-four institutions overall could be deemed to offer some comparable units, mostly in undergraduate courses. One clear, unforeseen conclusion was that university websites can be very frustrating to search, not only because of the obvious language barrier issues, but also because official sites are quite often not very user-friendly, delivering confusing or scant information. Based on the instability of the findings, we have decided, therefore, to neither attempt an assessment of the relative merits of each subject/unit/course, nor to gauge which universities are offering the most interesting, innovative units and courses. However, we have decided that the following information is worth documenting here, in order to show one aspect of the direction in which 'transnational/international film studies' may now be heading. In Australia, for instance, the most relevant film units offered with some apparent form of transnational philosophical orientation are variously called the following: Asian Cinema, Asia Pacific Film, Contemporary Cinema, Transnationalism, Contemporary Film Studies, Studies in World Cinema, Contemporary World Cinema/s, National Cinemas, Korean and Japanese Cinema: shaping identities through the lens, Contemporary Chinese Cinema, Counter Cinema, International Cinema. Across the globe, some transnationally oriented film units, again with reasonably illuminating descriptions, are entitled: Third World Cinema, International Cinema Origins to 1960, Global Genres and East Asian Cinema, Third Cinema, Focus on Emerging Cinemas, Third Cinema and Beyond, Topics in World Cinema, Contemporary Cinema, History of Film since 1959, Third World Film, Topics in Non-European Cinema. The jury is still out on the most appropriate, inclusive title.

${ }^{8}$ Astrid H. Gesche and Paul Makeham, 'Creating Conditions for Intercultural and International Learning and Teaching' in Meeri Hellstén and Anna Reid (eds), Researching International Pedagogies, Springer, Dordrecht, 2008, p. 243.

${ }_{9}^{9}$ Gesche and Makeham, p. 243.

10 Daya Kishan Thussu, 'Introduction' in Daya Kishan Thussu (ed), Internationalizing Media Studies, Routledge, London and New York, 2009, pp.2- 3.

${ }^{11}$ A number of critical commentators claim that the Howard Liberal government created a climate of racism in Australia through hardline policies regarding immigration, refugees, multiculturalism and Indigenous issues. See Greg Noble (ed.), Lines in the Sand: The Cronulla Riots, Multiculturalism and National Belonging, Institute of Criminology, Sydney, 2009; David Hollinsworth, Race and Racism in Australia, Thomson/Social Science Press, South Melbourne, 2006; Andrew Markus, Race: John Howard and the Remaking of Australia, Allen \& Unwin, Sydney 2001. 
12 Ginette Vincendeau, 'Issues in European Cinema', in John Hill and Pamela Church Gibson (eds), World Cinema: Critical Approaches, Oxford University Press, Oxford, 2000, p. 57.

13 Wimal Dissanayake, 'Issues in World Cinema', in John Hill and Pamela Church Gibson (eds), World Cinema: Critical Approaches, Oxford University Press, Oxford, 2000, p. 143.

14 Deardoff, p. 241.

15 For recent discussions and case studies on Internationalising the Curriculum, see Betty Leask, 'Internationalisation, Globalisation and Curriculum Innovation', in Meeri Hellstén and Anna Reid (eds), Researching International Pedagogies, Springer, Dordrecht, 2008, pp. 9-27; Astrid H. Gesche and Paul Makeham, 'Creating Conditions for Intercultural and International Learning and Teaching' in Meeri Hellstén and Anna Reid (eds), Researching International Pedagogies, Springer, Dordrecht, 2008, pp. 241-59; Jane Knight, 'Internationalization Remodelled: Definition, Approaches, and Rationales', Journal of Studies in International Education, vol. 8, no. 5, 2004, pp. 5-31.

16 Queensland University of Technology, Manual of Policies and Procedures, 4.3.3 Graduate Capabilities, <http://www.mopp.qut.edu.au/C/C_04_03.jsp\#C_04_03.03.mdoc>; accessed 1 April 2010.

${ }^{17}$ Queensland University of Technology Learning and Teaching Plan 2009-2013 Item 2.5 Integrate Crosscultural and International Dimensions into Curriculum Design and Learning Environments, <http://www.frp.qut.edu.au/services/planning/corpplan/documents/2009 -

2013LearningandTeachingPlan.pdf >; accessed 1 April, 2010.

${ }^{18}$ KPB206 International Cinema Unit Outline 2009.

${ }^{19}$ Deardoff, pp. 241-2.

${ }^{20}$ Papademetre, cited in Leask, p. 19.

${ }^{21}$ Leask, p. 19.

${ }^{22}$ Bill Hunter, George P. White and Galen C. Godbey, 'What Does it Mean to be Globally Competent?' Journal of Studies in International Education, vol. 10, 2006, p. 267. See also Gesche and Makeham. ${ }^{23}$ Leask, p. 16.

${ }^{24}$ For the framing of new interpretive paradigms, see the discussions on the impact of globalisation and internationalisation on cultural studies in Ackbar Abbas and John Nguyet Erni (eds), Internationalizing Cultural Studies: An Anthology, Blackwell Publishing, Malden, MA, 2005.

25 Richard Edwards and Robin Usher, Globalisation and Pedagogy: Space, Place and Identity, second edition, Routledge, Taylor and Francis Group, London and New York, 2008, p. 1.

26 Juana M. Sancho, 'Opening Students' Minds' in Meeri Hellstén and Anna Reid (eds), Researching International Pedagogies, Springer, Dordrecht, 2008, p. 260.

27 Knight, p. 6.

28 Ien Ang and Jon Stratton, 'Asianising Australia: Notes Toward a Critical Transnationalism in Cultural Studies', in Amit Sarwal and Reema Sarwal (eds), Creative Nation: Australian Cinema and Cultural Studies reader, SSS Publications, New Delhi, 2009, p. 314. 
${ }^{29}$ Sanjay Sharma, 'Teaching Diversity-Im/possible Pedagogy', Policy Futures in Education, vol. 4, no. 2, 2006, pp. 203-16; Meaghan Morris, 'Transnational Imagination in Action Cinema: Hong Kong and the Making of a Global Popular Culture', Inter-Asia Cultural Studies, vol. 5, no. 2, 2004, pp. 181-99; Konrad Ng, 'Notes on Film Pedagogy: Infusing Asian Studies into Undergraduate Curriculum', Flow, vol. 10, 2009, n.p., < http://flowtv.org/2009/09/notes-on-film-pedagogy-infusing-asian-studies-intoundergraduate-curriculum-konrad-ng-university-of-hawai\%E2\%80\%98i-at-manoa/>; accessed 15 April 2010; Yingjin Zhang, 'Comparative Film Studies, Transnational Film Studies: interdisciplinarity, Crossmediality, and Transcultural Visuality in Chinese Cinema', Journal of Chinese Cinemas, vol. 1, no. 1, 2007, pp. 27-40.

30 Meaghan Morris, 'Introduction: Hong Kong Connections', in Meaghan Morris, Siu Leung Li and Stephen Chan Ching-kiu (eds), Hong Kong Connections: Transnational Imagination in Action Cinema, Duke University Press, Durham and London, 2005, p. 5.

31 The World, directed by Jia Zhangke, 2004; See Ng, n.p.

32 Sharma, pp. 203-4; Bend It Like Beckham, directed by Gurinder Chadha, 2002.

33 Sharma, p. 213.

34 Zhang, pp. 37-8.

35 Elizabeth Ezra and Terry Rowden, 'General Introduction: What is Transnational Cinema?' in Elizabeth Ezra and Terry Rowden (eds), Transnational Cinema: The Film Reader, Routledge, London and New York, 2006, p. 2.

${ }^{36}$ Ella Shohat, 'Post-Third-Worldist Culture: Gender, Nation, and the Cinema', in Ezra and Rowden, pp. $39-41$.

37 Stephen Crofts, 'Reconceptualizing National Cinema/s', in Alan Williams (ed.), Film and Nationalism, Rutgers University Press, New Brunswick, 2002, p. 32.

38 Anthony R. Guneratne, 'Introduction: Rethinking Third Cinema', in Anthony R. Guneratne and Wimal Dissanayake (eds), Rethinking Third Cinema, Routledge, New York, 2003, p. 10.

${ }^{39}$ Ella Shohat and Robert Stam, Unthinking Eurocentrism: Multiculturalism and the Media, Routledge, London, New York, 1994.

40 Shohat, in Ezra and Rowden, p. 39.

41 Shohat, in Ezra and Rowden, p. 40.

42 Andrew Higson, 'The Limiting Imagination of National Cinema' in Ezra and Rowden, p. 23.

43 Jigna Desai, Beyond Bollywood: The Cultural Politics of South Asian Diasporic Film, Routledge, New York, 2004, p.4.

44 Shohat, in Ezra and Rowden, p. 53.

45 Ezra and Rowden, p. 1.

46 Desai, p. 3.

47 Pepi Leistyna, 'Introduction: Revitalizing the Dialogue: Theory, Coalition-Building, and Social Change' in Pepi Leistyna (ed.), Cultural Studies from Theory to Action, Blackwell, London, 2005, p. 2. 
48 Gary Hall and Clare Birchall (eds), New Cultural Studies: Adventures in Theory, Edinburgh University Press, Edinburgh, 2006, p. 23.

${ }^{49}$ Anne R. Hickling-Hudson, 'Improving Transnational Networking for Social Justice: 2001-2004', in Vandra Masemann, Mark Bray and Maria Manzon (eds), Common Interests, Uncommon Goals: Histories of the World Council of Comparative Education Societies and its Members, Springer, Netherlands, 2007, pp. 69-82; Anne R. Hickling-Hudson, 'Educating Teachers For Cultural Diversity and Social Justice', in Gudmund Hernes and Michaela Martin (eds), Planning For Diversity: Education in Multi-Ethnic and Multicultural Societies, International Institute for Education Planning (UNESCO), Paris, 2004, pp. 270307.

50 Hickling-Hudson, 'Educating Teachers For Cultural Diversity and Social Justice', pp. 270-1.

51 Amores Perros (Love's a Bitch), directed by Alejandro González Iñárritu, 2000; La Haine (Hate), directed by Mathieu Kassovitz, 1995; The Circle, directed by Jafar Panahi, 2000; Caché (Hidden), directed by Michael Haneke, 2005; Raise the Red Lantern, directed by Zhang Yimou, 1991; Water, directed by Deepha Mehta, 2005; Le fabuleux destin d'Amélie Poulai, aka Amélie, directed by Jean-Pierre Jeunet, 2001.

52 The Brisbane International Film Festival has been running successfully each year since 1994. Across eleven days, the festival attracts large audiences, and each year screens over two hundred films from many different countries, hosting a plethora of diverse international and national guests from the film industry.

53 Ezra and Rowden, p. 3.

54 Julian Stringer, 'Global Cities and the International Film Festival Economy', in Mark Shiel and Tony Fitzmaurice (eds), Cinema and the City: Film and Urban Societies in a Global Context, Blackwell, Oxford, 2001, p. 136.

55 Henry Giroux cited in Stephen Nathan Haymes, 'Toward a Pedagogy of Place for Black Urban Struggle' in Antonia Darder, Marta Baltodano and Rodolfo D. Torres (eds), The Critical Pedagogy Reader, RoutledgeFalmer, New York, 2003, p. 273.

${ }^{56}$ Jafar Panahi is an internationally acclaimed Iranian filmmaker, gaining recognition from film critics and theorists worldwide and receiving many awards including the Palme d'Or at Cannes, the Golden Lion, Venice Film Festival and the Silver Bear, Berlin Film Festival. In March 2010, he was jailed in Tehran and persecuted for his support of the opposition leader Mir Hossein Mousavi. He was released in late May 2010, after a hunger strike and much condemnation for his incarceration from the international film and human rights communities. At the time of writing, Panahi is still facing a trial and his future is uncertain.

${ }^{57}$ Hickling-Hudson, 'Educating Teachers For Cultural Diversity and Social Justice', p. 273.

58 Hunter, White and Godbey, p. 279.

${ }^{59}$ Monsoon Wedding, directed by Mira Nair, 2001; Water, directed by Deepha Mehta, 2005.

60 Morris, 'Transnational Imagination in Action Cinema', p. 181. 
61 C. Alejandra Elenes, 'Reclaiming the Borderlands: Chican/o Identity, Difference, and Critical Pedagogy' in Antonia Darder, Marta Baltodano, and Rodolfo D. Torres (eds) The Critical Pedagogy Reader, RoutledgeFalmer: New York, London, 2003, p. 191.

62 Elenes, pp. 195-6.

${ }^{63}$ Elenes, p. 198.

${ }^{64}$ Henry A. Giroux, Border Crossings: Cultural Workers and the Politics of Education, Routledge, New York 1992, and Peter McLaren, Critical Pedagogy and Predatory Culture: Oppositional Politics in a Postmodern Era, Routledge, New York, 1995 cited in Elenes, pp. 199-200.

65 Ang and Stratton, p. 314; Hickling-Hudson, 'Educating Teachers For Cultural Diversity and Social Justice', p. 271.

66 McLaren cited in Elenes, p. 200.

67 Gesche and Makeham, p. 254.

68 Gillan Bottomley, 'Politics, Policies and Possibilities: Interculturalism in France and Australia',

Communal Plural Journal of Transnational and Crosscultural Studies, vol. 8, no. 2, October 2000, p. 183.

${ }^{69}$ McLaren, 'Discussing Hope and Strategy through Education',

<http://dissidentvoice.org/Aug04/McLaren0817.htm>, accessed 29 April 2010.

70 Madagascar, directed by Fernando Perez, 1994, and Amores Perros (Love's a Bitch), directed by

Alejandro González Iñárritu, 2000; Laura Podalsky, 'Affecting Legacies: Historical Memory and Contemporary Structures of Feeling in Madagascar and Amores Perros', Screen, vol. 44, no. 3, Autumn 2003, p. 278.

71 Thomas Elsaessar, 'Subject Positions Speaking Positions from Holocaust Our Hitler and Heimat to Shoah and Schindler's List' in Vivian Sobchack (ed.), The Persistence of History: Cinema, Television and the Modern Event, Routledge, New York, 1996, cited in Podalsky, p. 279. 